\title{
Remote Sensing and Gis Based Study on River Siang Basin, India
}

\author{
Biplab Kumar Das ${ }^{1 *}$, Aloka Ghosh ${ }^{2}$ and Devashish Kar ${ }^{3}$ \\ ${ }^{1}$ Department of Zoology, Silapathar Science College, \\ Silapathar - 787059, Assam, India. \\ ${ }^{2}$ St. Francis de Sales School and Junior College, \\ Dhemaji - 787057, Assam, India \\ ${ }^{3}$ Department of Life Science and Bioinformatics and School of Life Sciences, \\ Assam University, Silchar-788011, Assam, India
}

\begin{abstract}
An analysis of the drainage network of a part of Siang River, Arunachal Pradesh, India, was undertaken to reveal the role of drainage water activity of the area. A number of fluvial geomorphic anomalies had been identified in the study area. Geologically the Siang basin was characterized by a wide spectrum of the alluvial segment of the basin was occupied by the sediments composed of gravel, sand silt and clay and found in the form of different terrace levels. Topographic analysis based on Digital Elevation Model (DEM) showed that $88 \%$ of the total basin areas were above $700 \mathrm{~m} \mathrm{msl}$.

River Siang basin was the eastern sub-basin and was drained by itself and it leaves Arunachal Pradesh to enter Assam to be joined by the Rivers Dibang and Lohit on its left bank to form the mighty River Brahmaputra. The sub-basin was comprised of the catchment of River Siang up to its confluence with River Siyom near Ponging.
\end{abstract}

Keywords: DEM, Slope, River Siang, East Siang, Arunachal Pradesh

\section{Introduction}

Geographic Information System (GIS) is a computer based information system used to digitally represent and analyze the geographic features present on the earth's surface and the events that were taking place on it. Burrough, (1986) defined GIS as "Set of tools for collecting, storing, retrieving at will, transforming and displaying spatial data from the real world for a particular set of purposes". The practical application of remote sensing techniques, in the mapping of the distribution of natural resources, their appraisal, conservation and management by using visual and digital analysis techniques.
Groundwater of river was one of the most valuable natural resources which support human health economic development and ecological diversity. Over-exploitation and unbeaten pollutions of this vital resource was threatening our ecosystems and even the life of future generations.

Uplift by mountain building forces changes fluvial landscapes (Bull 2007). The analysis of drainage networks is a powerful tool to detect recent tectonic activity and uplift (Ouchi 1985; Clark et. al 2004). A number of fluvial geomorphic anomalies have been identified in the drainage basins of Siang River within the East Siang valley in Arunachal Pradesh. The Himalayan belt in the north and the east has been controlling deposition of the stratigraphic formations and development of structural features throughout the tertiary period till recent time. Hence some of the observed drainage anomalies and geomorphic features have been influenced by recent tectonic activity within the various geomorphic features and drainage in seismically active areas provided evidence of neotectonic activity in response to movement along faults. Thus, the main objective of the present study is to examine the role of subsurface structures in affecting the courses, network and pattern of the rivers and consequently gave rise to drainage anomalies and other geomorphic features of River Siang (Das and Kar 2011; Kar 2013).

\section{Material and Methods}

Study site

The River Siang, is largest river of Brahmaputra river system, originates from Chema Yungdung Glacier near Kubi at $5150 \mathrm{~m}$ in Tibet. In Tibet it is 
popularly known as Tsang-Po, flows in West-East direction. After traversing a distance of about 1625 $\mathrm{km}$ river in Tibet and then it takes a turn in south direction, enters the territory of India near Tuting in the Upper Siang district of Arunachal Pradesh and flows through Nort 1 direction in East Siang district towards Assam and finally it merges with Lohit and Dibang in Assam and it becomes the mighty River Brahmaputra (Das et. al. 2014 a; Das and Kar 2015) Figure 1

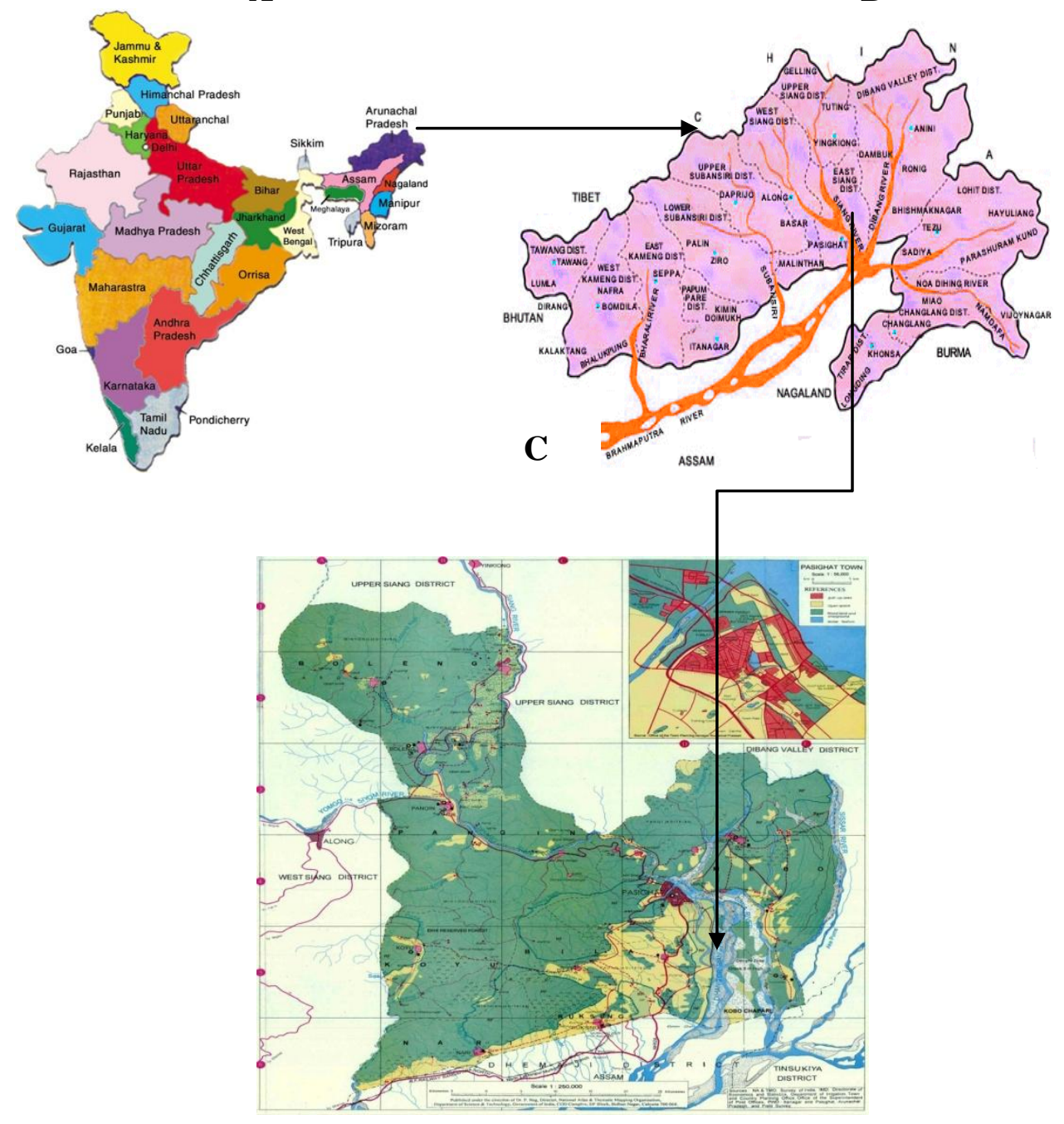

Fig 1: Map of (A) India indicating Arunachal Pradesh, (B) Arunachal Pradesh indicating to East Siang District, (C) In East Siang district highlighting River Siang (Study Area) of Arunachal Pradesh.

The study area covers a major part of East Siang District of Arunachal Pradesh latitudes 28002/43.16// - 28010/28.87//N and longitudes 95013/05.30//95021/39.00// E and altitude 501- $1681 \mathrm{Ft}$.; which is included in the Survey of India (SoI) topographic map nos. $82 \mathrm{O} / 11,82 \mathrm{O} / 12,82 \mathrm{O} / 15,82 \mathrm{O} / 16,82 \mathrm{P} / 9$, $82 \mathrm{P} / 10,82 \mathrm{P} / 11,82 \mathrm{P} / 12,82 \mathrm{P} / 13,82 \mathrm{P} / 14,82 \mathrm{P} / 15$,
$82 \mathrm{P} / 16,83 \mathrm{M} / 5$ and $83 \mathrm{M} / 9$ on $1: 50,000$ scale. The satellite Images LISS III were collected from the NRSC Hyderabad, India. The present study is confined to both the plain and hill areas because drainage anomalies in the plains and hills indicate the influence of subsurface structures, which are active in nature (Saders and Tabuchi, 2000; Saha et al., 2006; Talukdar, 2011; Das et al 2014 b). 


\section{Results}

\section{Digital Elevation Model (DEM) of River Siang}

The term digital elevation model or DEM is frequently used to refer to any raster representation of continuous elevation of a topographic surface with a common datum. Burrough (1986) had defined DEM as any digital representation of continuous variation of relief over place. With increased popularity of GIS technology and availability of DEMs the potential of using DEMs in studies of surface process had been widely recognized (Wharton, 1994).

In the present study, the SRTM data for River Siang was clipped and brought in to GIS environment for further analysis maintaining same datum and projection (WGS-1984), as in the satellite data. The SRTM DEM an elevation map was prepared in Arc-GIS 9.3 by classifying the DEM into six segments with different elevation differences. The maximum elevation was more than 3000 in the Indo-Tibet boarder while the minimum elevation was less than $150 \mathrm{~m}$. The minimum elevation of the area was less than $40 \mathrm{~m}$ near the confluence of River Siang with the Brahmaputra River. More than $83 \%$ of the total area lies above the $500 \mathrm{~m}$ elevation value and almost $17 \%$ of total area lies within the $500 \mathrm{~m}$ contour (Figure 2).

Areas were computed from the attributed values under different elevation zones, it revealed that c 5.6\% of the total areas lied within the $150 \mathrm{~m}$ elevation. This area mostly represents the low lying alluvial plain, wetlands, active channels and the flood plain. The elevations were mostly composed of older alluvium, river terrace occupying $1.2 \%$ of the total area. Within 350-625 m elevation interval occupying the $4.2 \%$ of the total area comes under the piedmont zone and the alluvial fan deposits. Areas at $>3000 \mathrm{~m}$ elevation lie along the N-E boundary of the catchment (Figure 2).

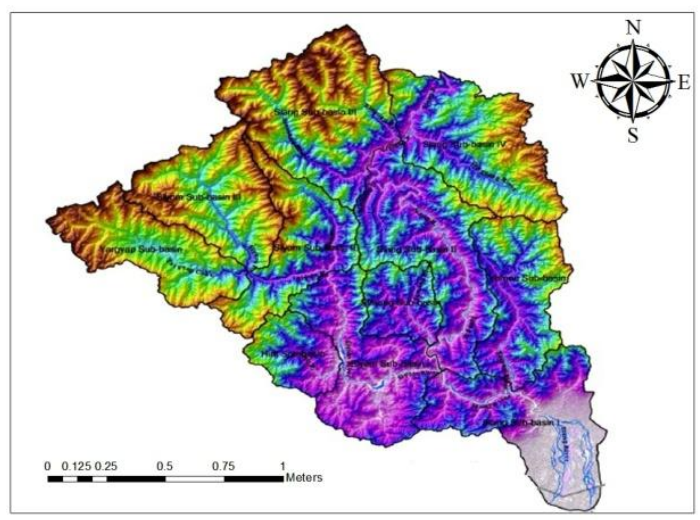

- Figure 2: DEM of River Siang Basin generated from ASTER G-DEM Satellite Data

\section{Slope of River Siang}

The two main derivatives of a continuous surface were slope and aspect. Slope was the rate of change in gradient of a surface and can be defined by a plane tangent to a topographic surface (Burrough, 1986). Analytically, slope gradient was defined as the maximum rate of change in altitude, aspect as the compass direction of this maximum rate of change. The angles being measured in a vertical plane along the direction in which the change of gradient was highest and this direction, along which the gradient was maximum, was the aspect at that point. Thus at any given point of surface comprises of two components namely gradient i.e. slope and the direction, i.e. aspect (Evans, 1964). Singh (1998) defined slope as angular inclination of terrain between hill tops and valley bottoms, resulting from the combination of many causative factors like geological structure, climate, vegetation cover, drainage, drainage texture and frequency, dissection index, relative relief, etc. The slope ranges between 0o-90o, while aspect ranges between 0o-360o. Slope gradient may be express as percent or in degrees (Figure 3).

Slope map of River Siang catchment was created from the SRTM DEM using Arc GIS 9.3. The slope map was classified into 6 different segments. It had been observed from the slope map that c $26 \%$ area had slope $<150$ and $80 \%$ of the area had a slope of 200. The alluvial plains showed comparatively low slope as 20 and these were gentle in nature. It was clearly observed that the piedmont area, alluvial and terraces had a moderate slope $150-250$. An area of c $45.75 \%$ of total area had a slope of $400-550$ which was the dominant slope in River Siang of Arunachal Pradesh.

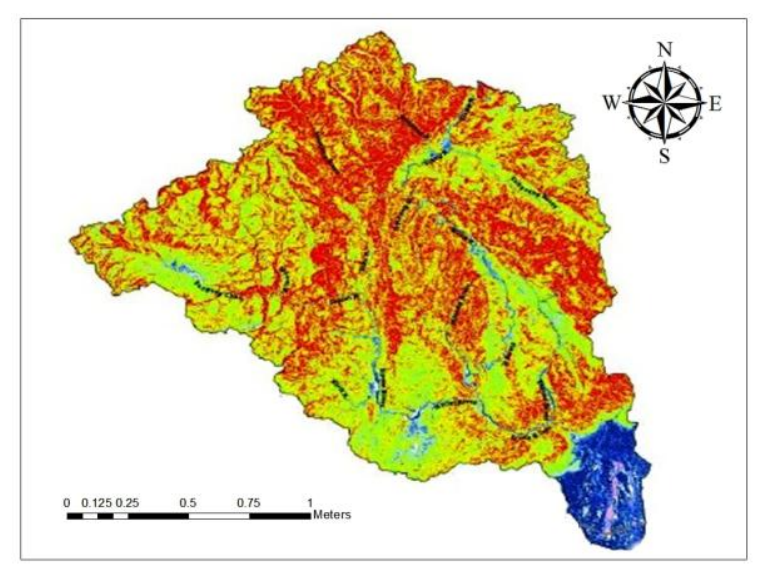

Figure 3: Slope Map of River Siang Basin 


\section{River Siang Sub-basin map}

River Siang basin was the eastern sub-basin and was drained by itself and it leaves Arunachal Pradesh to enter Assam to be joined by the Rivers Dibang and Lohit on its left bank to form the mighty River Brahmaputra. The sub-basin was comprised of the catchment of River Siang up to its confluence with River Siyom near Ponging. Some of the major right bank tributaries were Yeming, Sireng and Sibo Korong. Most of the habitations were found on the right bank of the river. Downstream of River Siang form a network of channels after emerging out of hills into plains then into Assam. River Sille was one of the main channels in the floodplains. The elevation varies from as low as $150 \mathrm{~m}$ to about 3000 m (Figure 4).

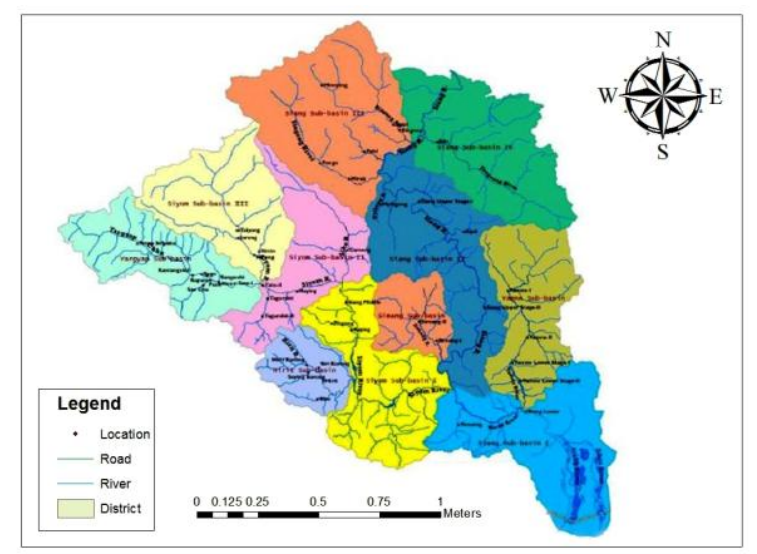

Figure 4: Sub-basins Map of Siang Basin

\section{Discussion}

Expansion of the river had taken place primarily through floodplain erosion. The study also revealed that, the parameters derived from SRTM DEM were helpful in fish habitat mapping. In the study it was found that SRTM data were more accurately represent rivers in the hilly areas. The associations of species with strong patterns of geology, land use and vegetation types were weak. The fishes of the River Siang basin provide some insights useful in managing invaded watersheds elsewhere.

River is one of the precious natural resources; due to rapid growth in population and urbanization the demand of potential ground water zone identification increases in the country as well as throughout the world. The collective use of the remote sensing and GIS based potential zone analysis had brought a new path in this field. Thus, the combination of RS and GIS techniques had employed in the present study and proved a powerful tool to understand the behavior of River Siang. Thus, the study gives an overview of the river water potentiality of the area and a quantitative amount of groundwater potential zones.

\section{Acknowledgement}

The authors are thankful to Assam University, Silchar and to the UGC, New Delhi for granting UGC-Fellowship to the First author.

\section{References}

[1] Bull, W. B. Tectonic Geomorphology of mountains. Oxford: Blackwell Pub. Pp. 316, (2007).

[2] Burrough P. A. Principles of Geographical Information Systems for Land Resources Assessment. Oxford University Press, New York, (1986).

[3] Clark, M. K., Schoenbohm, L. M., Royden, L. H.,Whipple, K. X., Burchfiel, B. C. and Zhang, X. Surface uplift, tectonics, and erosion of eastern Tibet from large-scale drainage patterns. Tectonics. 23: 1$10,(2004)$.

[4] Das, B. K. and Kar, D. Habitat Mapping, Spatial Analysis of Fish Diversity of River Subansiri during winter season in Assam and Arunachal Pradesh (India). Environment and Ecology. 29 (4A): 19481951, (2011).

[5] Das, B. K.; Boruah, P. and Kar, D. Study of Seasonal Variation of Water Quality of River Siang in Arunachal Pradesh, India. IOSR Journal of Environmental Science, Toxicology and Food Technology (IOSR-JESTFT). 8 (2IV): 11-20, (2014 a).

[6] Das, B. K.; Boruah, P. and Kar. D. Potential Application of Geographic Information System (GIS) and Remote Sensing (RS) in River Analysis. International Journal of Recent Scientific Research. 5 (4): 828-830, (2014 b).

[7] Das, B. K. and Kar, D. "Physico-chemical parameters and drainage types of River Siang in Arunachal Pradesh, India" in Mishra, G. C. (eds.) Conceptual Framework and Innovations in Agroecology and Food Sciences, Krishi Sanskriti Publications, New Delhi, India. pp. 53-56, (2015).

[8] Evans, P. The tectonic framework of Assam. Jour. Geol. Soc. Ind. 5: 80-96, (1964).

[9] Kar, D. Wetlands and Lakes of the World. Springer, London. pp. xxx + 687, (2013).

[10] Ouchi, S. Response of alluvial rivers to slow active tectonic movement. Geological Society of America Bulletin. 96: 504-515, (1985).

[11] Saders, R. and Tabuchi, S. Decision Support System for Flood Risk Analysis for the River Thames, United Kingdom. J. Amer. Soc. 66: 4-10, (2000).

[12] Saha, K. K.; Dave, H. D. and Mitra, D. D. Study of Tectonic Elements of Punjab Plains from satellite imagery, drainage network and gravity anomalies. 6th International Conference and Exposition on Petroleum Geophysics "Kolkata 2006". 43-48, (2006).

[13] Singh, S. Physical Geography. Prayag Pustak Bhawan, Allahabad, India. pp. 641, (1998).

[14] Talukdar, R. Geo-morphological study of the Jia Bharali River catchment, N. E. India. pp. xii+275, (2011).

[15] Wharton, G. Progress in the use of drainage network indices for rainfall-runoff modelling and runoff prediction. Progress in Physical Geography. 18: 539557, (1994). 